Schaechter, M., MaAløe, O. \& KJeldgaArd, N. O. (1958). J. gen. Microbiol. 19, 592-606

\title{
Dependency on Medium and Temperature of Cell Size and Chemical Composition during Balanced Growth of Salmonella typhimurium
}

\author{
By M. SCHAECHTER*, O. MAALøE AND N. O. KJELDGAARD \\ State Serum Institute, Copenhagen, Denmark
}

SUMMARY: Cell mass, the average number of nuclei/cell and the content of RNA and DNA were studied in Salmonella typhimurium during balanced (steady state) growth in different media. These quantities could be described as exponential functions of the growth rates afforded by the various media at a given temperature. The size and chemical composition characteristic of a given medium were not influenced by the temperature of cultivation. Thus, under conditions of balanced growth, this organism exists in one of a large number of possible stable physiological states.

The variations in mass/cell are due to changes in the number of nuclei/cell as well as in mass/nucleus. An increase in the number of ribonucleoprotein particles at higher growth rates could, it appears, largely account for the increase in mass/nucleus. Calculations indicate that the rate of protein synthesis per unit RNA is nearly the same at all growth rates.

It is a classic observation that bacterial cells increase in size during the lag which precedes cell division in a newly-inoculated culture, and become smaller again during the period of declining growth (Henrici, 1928). It is also well known that increase in size and enrichment in ribonucleic acid go hand in hand (Malmgren \& Hedén, 1947; Morse \& Carter, 1949; Wade, 1952; Gale \& Folkes, 1958). Previously, interest has been focused mainly on the striking difference between the small, non-dividing cells of an outgrown culture and the larger forms typical of rapid growth. Hence, cells are often described as 'resting' or 'exponentially growing' and these conditions implicitly considered to be alternative physiological states.

We have studied cells of Salmonella typhimurium during unrestricted, balanced growth in a variety of media and at different temperatures. The term 'cell' is used throughout this and the following paper to denote either a colony-forming unit or a microscopically visible rod. In both cases the unit may contain more than one nucleus. The terms 'unrestricted and 'balanced' are defined in the discussion. In each case the growth rate, cell size, and the amounts of ribonucleic acid (RNA) and desoxyribonucleic acid (DNA) and the average number of nuclei/cell were determined.

These experiments show that a large number of physiological states exists, each of which is characterized by a particular size and chemical composition of the cells. At a given temperature, average mass, RNA, DNA and number of

* Present address : Department of Microbiology, College of Medicine, University of Florida, Gainesville, Florida, U.S.A. 
nuclei/cell can be described as exponential functions of the growth rate. In a given medium, cell size and composition are almost independent of the growth temperature. The characteristics of the cells would therefore seem to be determined primarily by the pattern of biochemical activities imposed by the medium.

The figures obtained for mass, RNA and DNA/cell permit estimates to be made of the quantities of protein and nucleic acids synthesized/cell/minute in different media at a given temperature. These calculations suggest that, over a wide range of growth rates, the amount of protein synthesized/minute is roughly proportional to the RNA content of the cell; or that, /unit of RNA, the number of protein molecules synthesized/minute is almost independent of the growth rate.

\section{METHODS}

Bacteria. The wild-type strain of Salmonella typhimurium used in this work was previously employed in this laboratory (Lark \& Maaløe, 1954). The tryptophan-requiring mutant try $A-8$ of $S$. typhimurium, kindly supplied by Dr M. Demerec, was used in the continuous-culture experiments.

Culture media. The media employed and the growth rates they supported are listed in Table 1. Amino acids and sugars were added after separate sterilization. All media were adjusted to $\mathbf{p H ~} \mathbf{7 \cdot 0}$.

Growth conditions. The organisms were grown in several hundred $\mathrm{ml}$. volumes of medium through which air was constantly bubbled. Balanced growth was maintained by diluting with equal volumes of fresh medium at intervals corresponding to the average generation time. Before sampling, cultures were grown for several hours with frequent checks of the optical density in order to ensure that a constant growth rate had been established. As a rule, the optical density (at $450 \mathrm{~m} \mu$, and $1 \mathrm{~cm}$. path) was kept between $0 \cdot 200$ and $0 \cdot 400$. In all media strictly exponential growth is maintained until the optical density reaches $\mathbf{0 . 8 0 0}$ or more. This optical density corresponds to $1 \cdot 2-6 \cdot 2 \times 10^{8}$ bacteria $/ \mathrm{ml}$. and to $c .140 \mu \mathrm{g}$. $/ \mathrm{ml}$. bacterial dry weight in the range of culture media employed.

Continuous culture growth. A continuous culture device using an automatic pipetting machine as feeding pump was employed (Formal, Baron \& Spilman, 1956). The culture volume of $600 \mathrm{ml}$. contained in a cylinder $6 \mathrm{~cm}$. in diameter, was aerated through a fritted glass plate. Efficient stirring was produced by the vigorous aeration; thus an added drop of dye solution became uniformly mixed in the culture liquid well within 1 sec. Excess fluid was continuously removed from the surface by suction. The dilution rate $D$ (Monod, 1950) was varied by adjusting both the numbers of strokes delivered by the pipetting machine (10-15/min.) and the volume of medium added/stroke (0.5$1.5 \mathrm{ml}$.). Mutant $\operatorname{tr} y \boldsymbol{A}-8$ was grown with tryptophan as limiting factor in the casamino-acids medium with $1 \mu \mathrm{g}$. tryptophan $/ \mathrm{ml}$. Feeding was routinely started just after the culture had exhausted the tryptophan present at the time of inoculation. Sampling for the various analyses was carried out after 
Table 1. Culture media employed

\begin{tabular}{|c|c|c|c|c|}
\hline No. & Medium & Concentration & $\begin{array}{l}\text { No. of } \\
\text { expt. }\end{array}$ & $\begin{array}{c}\text { Average } \\
\text { growth } \\
\text { rate in } \\
\text { doublings/ } \\
\text { hr. }\end{array}$ \\
\hline $\mathbf{1}$ & Brain + heart infusion & Full strength & $\mathbf{1}$ & $2 \cdot 80$ \\
\hline 2 & Nutrient broth & Meat extract $+1 \%$ peptone & $\mathbf{3}$ & $2 \cdot 75$ \\
\hline $\mathbf{3}$ & Yeast extract + glucose & Full strength $+0.2 \%$ glucose & 2 & $2 \cdot 73$ \\
\hline 4 & Placenta broth & Full strength & 1 & $\mathbf{2} \cdot 70$ \\
\hline 5 & Nutrient broth & Dil. 1:2 with medium no. 14 & 3 & $2 \cdot 60$ \\
\hline 6 & Nutrient broth & Dil. $1: 5$ with medium no. 14 & 9 & $\mathbf{2} \cdot \mathbf{4 0}$ \\
\hline 7 & Casamino acids $(a)$ & $\begin{array}{l}1.5 \% \text { (Difco) }+0.01 \% \text { trypto- } \\
\text { phan in medium no. } 14\end{array}$ & 2 & $\mathbf{2 \cdot 0 0}$ \\
\hline 8 & 199 Tissue-culture medium & See $^{(b)}$ & $\mathbf{1}$ & 1.88 \\
\hline 9 & 20 amino acids & $\begin{array}{l}\text { As in medium No. } 8+\text { salt } \\
\text { solution }^{(0)}\end{array}$ & $\mathbf{1}$ & $1 \cdot 83$ \\
\hline 10 & Amino acids pool $2^{(d)}$ & $\begin{array}{l}\text { As in medium No. } 8 \text { + salt } \\
\text { solution }(\epsilon)\end{array}$ & $\mathbf{2}$ & $1 \cdot 46$ \\
\hline 11 & Amino acids pool $3^{(e)}$ & $\begin{array}{l}\text { As in medium No. } 8+\text { salt } \\
\text { solution }\end{array}$ & $\mathbf{2}$ & $1 \cdot 38$ \\
\hline 12 & Amino acids pool $4^{(f)}$ & $\begin{array}{l}\text { As in medium No. } 8+\text { salt } \\
\text { solution }^{(c)}\end{array}$ & $\mathbf{1}$ & $1 \cdot 25$ \\
\hline 13 & Amino acids pool $1^{(g)}$ & $\begin{array}{l}\text { As in medium No. } 8+\text { salt } \\
\text { solution(c) }^{(c)}\end{array}$ & $\mathbf{1}$ & $\mathbf{1} \cdot \mathbf{2 2}$ \\
\hline 14 & Glucose salt (medium $\mathbf{K}$ ) & $0.2 \%+$ Salt solution $(c)$ & $\boldsymbol{9}$ & $1 \cdot 20$ \\
\hline 15 & Succinate salt & $0.2 \%+$ Salt solution $(e)$ & $\mathbf{2}$ & 0.94 \\
\hline 16 & Lactate salt & $0.2 \%+$ Salt solution ${ }^{(c)}$ & $\mathbf{2}$ & 0.90 \\
\hline 17 & Dulcitol salt & $0.05 \%$ + Salt solution ${ }^{(c)}$ & $\mathbf{1}$ & $0 \cdot 83$ \\
\hline 18 & Aspartate salt & $0.012 \%+$ Salt solution ${ }^{(c)}$ & $\mathbf{1}$ & $\mathbf{0 . 8 3}$ \\
\hline 19 & Methionine 'salt & $0.06 \%+$ Salt solution $(c)$ & $\mathbf{1}$ & 0.81 \\
\hline 20 & Histidine salt & $0.04 \%$ + Salt solution(c) & 1 & 0.78 \\
\hline 21 & Threonine salt & $0.012 \%+$ Salt solution $(\mathrm{e})$ & 1 & 0.63 \\
\hline 22 & Lysine; salt & $0.014 \%+$ Salt solution $(0)$ & 1 & 0.62 \\
\hline
\end{tabular}

(a) This medium, with limiting tryptophan, was employed in the bactostat experiments.

(b) Morgan's medium (Salk, Youngner \& Ward, 1954) was employed without antibiotics, indicator and solutions $\mathbf{H}-\mathbf{K}, \mathbf{I}, \mathbf{J}, \mathbf{Q}, \mathbf{G}$ and $\mathbf{P}$.

(c) Salt solution: $\mathrm{MgSO}_{4} .7 \mathrm{H}_{2} \mathrm{O}, 0.1$; citric acid, $1.0 ; \mathrm{Na}_{2} \mathrm{HPO}_{4} .2 \mathrm{H}_{2} \mathrm{O}, 5.0 ; \mathrm{Na}\left(\mathrm{NH}_{4}\right)$ $\mathrm{HPO}_{4} .4 \mathrm{H}_{2} \mathrm{O}, 1.74 ; \mathrm{KCl}, 0.74 \mathrm{~g} . / \mathrm{l}$. Made up as a $50 \times$ concentrate. This solution did not support perceptible growth without the addition of other carbon sources.

(d) Threonine, tyrosine, cysteine, histidine, phenylalanine, isoleucine, hydroxyproline and arginine.

(e) Phenylalanine, isoleucine, hydroxyproline, arginine, leucine, aspartic acid, glycine and tryptophan.

(f) Leucine, aspartic acid, glycine, tryptophan, glutamic acid, alanine, serine and valine.

(g) Glutamic acid, alanine, serine, valine, glutamine, lysine, methionine and proline.

not less than $6 \mathrm{hr}$. of growth. During this period the optical density remained practically constant at about $\mathbf{0} \cdot \mathbf{4 0 0}$.

Mass determination. The values of mass/cell are expressed as the optical density at $450 \mathrm{~m} \mu\left(1 \mathrm{~cm}\right.$. path) given by a suspension containing $10^{7}$ cells/ $\mathrm{ml}$. The optical density was found to be proportional to the dry weight, irrespective of the cell size. Optical density $0 \cdot 100$ corresponds to $17-18 \mu \mathrm{g}$. dry weight/ml.

Plate counts. Samples of the cultures were diluted in steps representing a total dilution of 2 or $4 \times 10^{-4}$. The original sampling was done with a 0.025 or $0.050 \mathrm{ml}$. constriction pipette and the subsequent steps were carried out with 
$0 \cdot 1 \mathrm{ml}$. serological pipettes. For each value of Fig. 1 plating was done from at least six individual dilutions performed within $10 \mathrm{~min}$. and adjusted to give between 300 and 600 colonies/plate. The viable counts were fitted to the growth curve determined by the optical-density measurements. It was found that the number of viable cells $/ \mathrm{ml}$. could be measured with an error of less than $10 \%$.

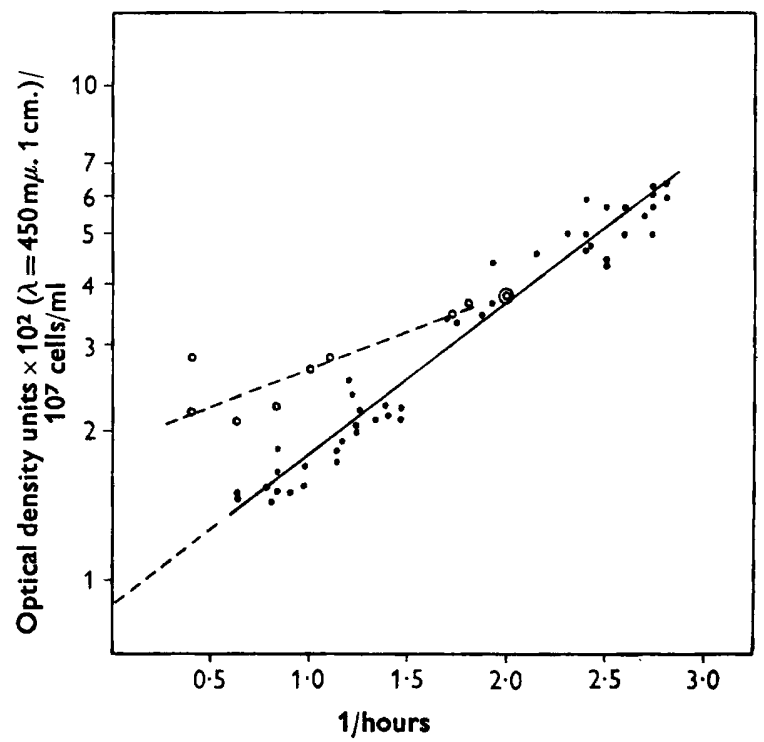

Fig. 1. Dependency of cell mass on growth rate at $37^{\circ}$. From the optical-density (mass) measurements and the viable counts in the different media, values for optical density $/ 10^{7}$ cells $/ \mathrm{ml}$. were calculated. The logarithm of these values is plotted against the growth rate expressed as doublings/hr. (๑). The stippled line corresponding to the open rings and to the double-ringed point represents results from continuous culture experiments plotted against the dilution rate $(0)$.

Chemical analysis. For nucleic-acid determinations, $40 \mathrm{ml}$. samples were frozen quickly in a solid $\mathrm{CO}_{2}+$ ethanol bath. They were thawed and centrifuged in a cooled Servall angle centrifuge at 12,000 rev./min. for $20 \mathrm{~min}$., the sediments were resuspended in $2.5 \mathrm{ml}$. of cold saline and $0.1 \mathrm{ml}$. of $70 \%$ perchloric acid was added to $2 \mathrm{ml}$. of this suspension. The material was heated to $70^{\circ}$ for $30 \mathrm{~min}$., centrifuged and the supernate collected for colorimetric sugar tests. Deoxyribose was determined by the procedure of Burton (1956) on $1.0 \mathrm{ml}$. of the acid extract. Ribose determinations following the method of Kerr \& Seraidarian (1945) were performed on $0.1 \mathrm{ml}$. of the extract. All spectrophotometry was done with a Zeiss Model PMQ II spectrophotometer employing $1 \mathrm{~cm}$. cuvettes. Most of the values presented in Figs. 2 and 3 are averages of four independent determinations.

Nuclear staining. Fixation with $\mathrm{OsO}_{4}$ and staining with thionine were carried out according to Lark, Maaløe \& Rostock (1955), except that acid hydrolysis was extended to $6 \mathrm{~min}$. This procedure is not primarily intended to preserve fine structural detail but, in the organism used, it reveals the same 


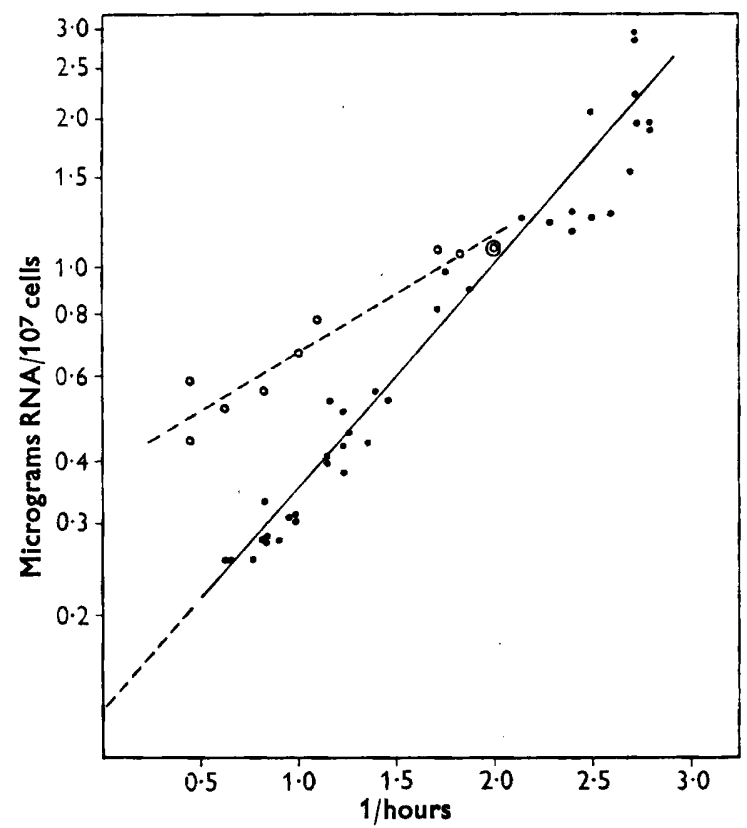

Fig. 2. Dependency of cellular ribonucleic acid on growth rate at $37^{\circ}$. The RNA content of the cultures was calculated from the ribose determinations. ( $\mu \mathrm{g}$. RNA $=\mu \mathrm{g}$ ribose $\times 4.91$ ). The logarithm of the RNA values (micrograms) $/ 10^{7}$ viable cells is plotted against the growth rate (๑). The stippled line corresponding to the open rings and to the double-ringed point represents results from continuous culture experiments, plotted against the dilution rate $(0)$.

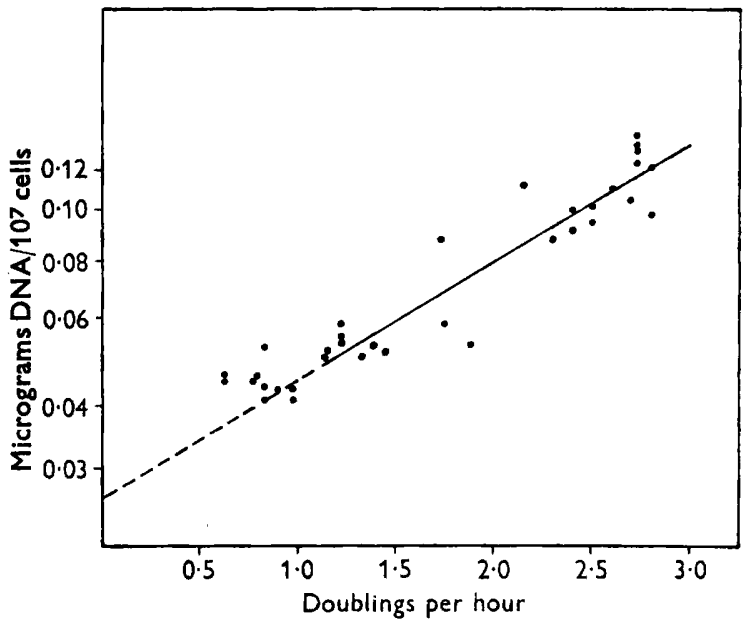

Fig. 3. Dependency of cellular deoxyribonucleic acid on growth rate at $37^{\circ}$. The DNA content of the cultures was calculated from the deoxyribose determinations $(\mu \mathrm{g}$. DNA $=$ $\mu \mathrm{g}$. deoxyribose $\times 2 \cdot 44$ ). The logarithm of the DNA values $\mu \mathrm{g} . / 10^{7}$ viable cells is plotted against the growth rate. 
number of individual staining bodies in each cell as that obtained by other methods. For reasons of ease of observation the stained preparations were examined under phase contrast microscope (Zeiss). Between 300 and 400 cells per sample were scored as one-, two-, or four-nucleated taking into consideration, when possible, that some of the rods consisted of sister cells in different degrees of separation. A subjective criterion had to be employed in order to score a cell containing two adjacent bodies as one- or two-nucleated. However, repeated counts of the same preparation after an interval of months, or duplicate counts by different observers, always gave results compatible with the sampling error.

\section{RESULTS}

Balanced growth was maintained at $37^{\circ}$ in the different media listed above (Table 1) and samples analysed for mass (optical density) RNA, DNA, viable counts and number of nuclei/cell. The results are presented in Figs. 1-3 in which logarithms of mass, RNA and DNA per viable cell are plotted against

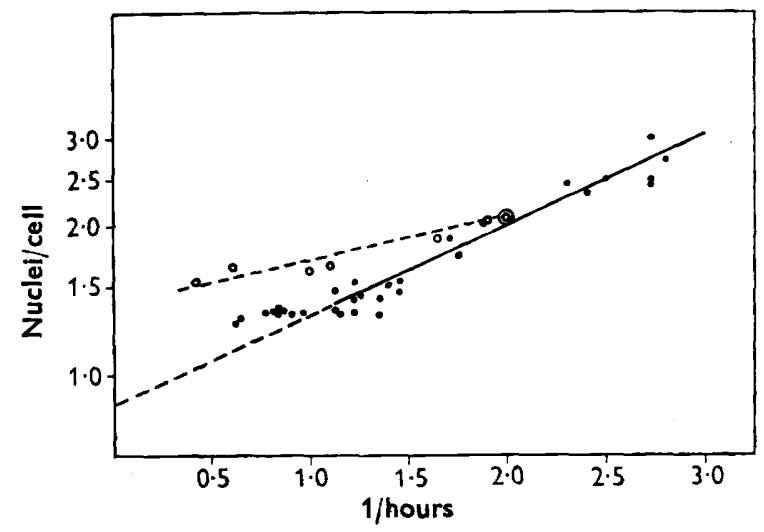

Fig. 4. Dependency of the number of nuclei/cell on growth rate at $37^{\circ}$. The average number of nuclei/cell was calculated from direct counts on stained preparations. The logarithm of the values is plotted against the corresponding growth rate (৫). The stippled line corresponding to the open rings and the double-ringed point represents results from continuous culture experiments, plotted against the dilution rate $(0)$.

the growth rate. Figure 4 represents a similar plot for nuclei/cell. Regression analysis showed that the straight lines drawn in Figs. 1-4 adequately represent the observed values. The individual determinations deviate only slightly more from the lines than is to be expected when the combined errors of the chemical analysis and the viable counts are taken into account. For ease of comparison, the increments on the logarithmic scale are the same in all figures.

In Fig. 1, the unbroken line fitted to the solid points shows that cell mass just about doubles/unit increase in doublings/hr. The extrapolation to zero growth rate suggests that the minimal bacterial size would be about half that of a cell growing in glucose-salt medium. This minimal size was actually attained under conditions of nitrogen starvation (see following paper). 
Dr K. F. A. Ross kindly carried out measurements on the thickness of formalin-fixed organisms by interference microscopy using a modification of the technique he developed in 1955 (Ross, 1957). He obtained the following figures for the average of ten determinations per sample: $1.43 \mu$ for a culture growing in medium no. 2 at 2.73 doublings $/ \mathrm{hr}$. (d/hr.); $1.22 \mu$ for $1.85 \mathrm{~d} / \mathrm{hr}$. (medium no. 7); $0.93 \mu$ for $1.00 \mathrm{~d} / \mathrm{hr}$. (medium no. 14) and $0.87 \mu$ for $0.61 \mathrm{~d} / \mathrm{hr}$. (medium no. 22). The cell volumes obtained from these figures and from estimates of cell lengths were found to be proportional to the cell mass, as estimated from optical density measurements.

Figs. 2 and 3 show that, per unit increase in doublings/hr., the amount of RNA/cell increases by $\times \mathbf{2 \cdot 8 5}$ that of DNA/cell by $\times 1 \cdot 73$. The corresponding factor for the average number of nuclei/cell, derived from Fig. 4 , is $\times 1.55$. At $37^{\circ}$, the four parameters examined may thus be described as exponential functions of the growth rate and can be arranged as follows, with regard to the slopes of the semilogarithmic plots: $R N A>$ mass $>$ DNA $\geqslant$ nuclei/cell.

It is to be understood that all 'per cell values' are based, either on viable counts, or, in the case of nuclei, on cytological observations. Simultaneous haemocytometer and colony counts repeatedly showed that, under conditions of balanced growth, viable and total counts did not differ significantly. Counting unstained cells in the phase contrast microscope showed that, in all media, approximately $75 \%$ of the units appeared to be true single cells, the remaining $\mathbf{2 5} \%$ were 'doublets' representing incompletely separated sister cells. In Figs. 1-3, an approximate correction for doublets can be made by multiplying the ordinate values by $0 \cdot 8$.

The figures for nuclei/cell (Fig. 4) are based on direct counts of stained preparations. It was not always possible after staining to distinguish between single elements and doublets, particularly when the cells are small. Thus, at the lowest growth rates (smallest cells) uninucleated sister cells which remained attached to one another were probably often scored as binucleates. When the number of nuclei/cell is close to unity a bias of this kind may increase the observed value significantly over the true one. This might be the reason why, in Fig. 4, the experimental points deviate from the straight line at low rates, and it may also explain that the values for DNA/nucleus, which at higher growth rates are found to vary in a random manner around the mean value, decrease slightly, but significantly, in this region.

A number of experiments were carried out with cultures grown at lower temperatures. In Table 2 results obtained at $37^{\circ}$ and at $25^{\circ}$ with five different media are compared. In all cases, the growth rate at $25^{\circ}$ was about half that at $37^{\circ}$; nevertheless, mass, RNA, DNA and number of nuclei/cell remained nearly constant for a given medium. In broth or in the amino-acid medium the figures for nuclei/cell are somewhat higher at $37^{\circ}$ than at $25^{\circ}$, but the experiments at $25^{\circ}$ are few and the observed difference is probably not significant. Moreover, extensive chemical and cytological studies previously carried out with the same organism showed that, in broth, identical values for DNA and for nuclei/cell are obtained at $25^{\circ}$ and at $37^{\circ}$ (Lark \& Maaløe, 1956; Lark, Maaløe \& Rostock, 1955). 
In fact, our data suggest that more extensive analyses of $25^{\circ}$ cultures would permit graphs to be constructed which would be identical with those of Figs. 1-4 if the growth rate values on the abscissa were reduced to half. Thus, within the temperature range studied, the size and chemical composition of the cells are related to the growth rate only in so far as it depends on the medium.

Table 2. The effect of temperature on cell size and composition

\begin{tabular}{|c|c|c|c|c|c|c|c|}
\hline Medium & $\begin{array}{l}\text { No. of } \\
\text { expts. }\end{array}$ & $\begin{array}{c}\text { Growth } \\
\text { temp. } \\
\left({ }^{\circ} \mathrm{C.}\right)\end{array}$ & $\begin{array}{c}\text { Doublings/ } \\
\text { hr. }\end{array}$ & $\begin{array}{c}\text { Optical } \\
\text { density* } \\
\text { mass }\end{array}$ & RNA* & DNA* & $\begin{array}{c}\text { Nuclei/ } \\
\text { cell }\end{array}$ \\
\hline No. 6 (broth) & $\begin{array}{l}2 \\
4\end{array}$ & $\begin{array}{l}\mathbf{2 5} \\
\mathbf{3 7}\end{array}$ & $\begin{array}{l}1 \cdot 06 \\
2 \cdot 40\end{array}$ & $\begin{array}{l}5 \cdot 80 \\
5 \cdot 00\end{array}$ & $\begin{array}{l}1.64 \\
1.44\end{array}$ & $\begin{array}{l}0.130 \\
0.095\end{array}$ & $\begin{array}{l}\mathbf{2} \cdot 85 \\
\mathbf{2} \cdot 50\end{array}$ \\
\hline $\begin{array}{l}\text { No. } 9 \text { (amino } \\
\text { acids) }\end{array}$ & $\begin{array}{l}1 \\
2\end{array}$ & $\begin{array}{l}25 \\
37\end{array}$ & $\begin{array}{l}0 \cdot 88 \\
1 \cdot 83\end{array}$ & $\begin{array}{l}3 \cdot 66 \\
3 \cdot 76\end{array}$ & $\begin{array}{r}0.92 \\
0.97\end{array}$ & $\begin{array}{l}0.085 \\
0.056\end{array}$ & $\begin{array}{l}2 \cdot 05 \\
1 \cdot 74\end{array}$ \\
\hline No. 14 (glucose) & $\begin{array}{l}\mathbf{3} \\
5\end{array}$ & $\begin{array}{l}25 \\
37\end{array}$ & $\begin{array}{l}0.65 \\
1 \cdot 20\end{array}$ & $\begin{array}{l}2 \cdot 32 \\
1 \cdot 92\end{array}$ & $\begin{array}{l}0.56 \\
0.44\end{array}$ & $\begin{array}{l}0.065 \\
0.048\end{array}$ & $\begin{array}{l}1 \cdot 46 \\
1 \cdot 38\end{array}$ \\
\hline $\begin{array}{l}\text { No. } 15 \\
\text { (succinate) }\end{array}$ & $\begin{array}{l}\mathbf{2} \\
\mathbf{2}\end{array}$ & $\begin{array}{l}25 \\
37\end{array}$ & $\begin{array}{l}0.48 \\
0.93\end{array}$ & $\begin{array}{l}1.47 \\
1.60\end{array}$ & $\begin{array}{l}0 \cdot 39 \\
0 \cdot 39\end{array}$ & $\begin{array}{l}0.088 \\
0.042\end{array}$ & $\begin{array}{l}1 \cdot 31 \\
1 \cdot 33\end{array}$ \\
\hline $\begin{array}{l}\text { No. } 16 \\
\text { (lactate) }\end{array}$ & $\begin{array}{l}\mathbf{2} \\
\mathbf{2}\end{array}$ & $\begin{array}{l}\mathbf{2 5} \\
\mathbf{3 7}\end{array}$ & $\begin{array}{l}\mathbf{0 . 5 0} \\
\mathbf{0 . 9 0}\end{array}$ & $\begin{array}{l}1 \cdot 50 \\
1 \cdot 61\end{array}$ & $\begin{array}{l}\mathbf{0} \cdot 39 \\
\mathbf{0} \cdot 39\end{array}$ & $\begin{array}{l}0.038 \\
0.039\end{array}$ & $\begin{array}{l}1.30 \\
1 \cdot 35\end{array}$ \\
\hline
\end{tabular}

* The units for mass, RNA and DNA per cell are the same as in Figs. 1-3, respectively.

The results of the analysis of mass, RNA and nuclei/cell from the continuous culture experiments are presented as open circles in Figs. 1, 2 and 4. The logarithms of cell contents are plotted against the dilution rate $D$ expressed in doublings of culture volume/hr. Monod (1950) and Novick \& Szilard (1950) have shown that, in the ideal continuous culture system, $D$ is related to the growth rate $\mu$ (in doublings/hr.) by the equation $\mu=D / \ln 2$. As will be seen, this situation was not obtained throughout our experiments. In Figs. 1, 2, and 4 the points marked with a double ring correspond to the maximum rate $(\mu=2 \cdot 0)$ attainable during unrestricted growth of strain try $A-8$ in the Casamino acid medium with excess tryptophan. Thus, for values of $D$ higher than $\mathbf{1} \cdot \mathbf{3 8}$, corresponding to $\mu=\mathbf{2} \cdot \mathbf{0}$, the theoretical growth rate calculated from the above formula exceeds the maximum values for unrestricted growth. $D$ values as high as $\mathbf{1 \cdot 7 7}$, corresponding to a theoretical growth rate of $\mathbf{2 \cdot 6}$, have been obtained in our experiments. A similar discrepancy between the calculated and the maximum growth rates was reported by Herbert, Elsworth \& Telling (1956) and Powell (1956) who attributed it to imperfect mixing.

It will be seen from Figs. 1, 2 and 4, that the values for mass, RNA and nuclei/cell for organisms grown in continuous culture may also be described as exponential functions of the growth rate. The slopes of the stippled lines drawn in Figs. 1, 2, and 4 are considerably less than those obtained for unrestricted growth, indicating that the lower the dilution rate, the more do the values exceed those from batch cultures. The same trend was observed for DNA, but the data are not included in Fig. 3 because of considerable scatter in the values obtained. 


\section{DISCUSSION}

Our discussion falls into three parts : (1) An account of the physiological states imposed by the medium under unrestricted and restricted, balanced growth. (2) A representation of related and otherwise relevant data from the literature. (3) An analysis of our findings in terms of the major synthetic activities of the bacterial cell.

(1) In liquid cultures of low bacterial concentration, cells continue to grow for a long time in a virtually unchanging environment. This ideal condition leads to the establishment of a steady state of balanced growth, which can be prolonged at will by appropriate dilutions of the culture. In Campbell's apt formulation (Campbell, 1957), growth is said to be balanced over a time interval if, during the interval, every 'extensive' property of the system increases by the same factpr. Failure to maintain balanced growth throughout an experiment makes it impossible to relate any measured quantity to the growth rate in a direct way.

When the density of a culture approaches saturation the growth rate gradually decreases and it increases upon subsequent dilution with fresh medium. In either case the changes in rates of cell division and of mass synthesis do not run parallel; as a rule, the rate of cell division remains unchanged for some time after the rate of mass synthesis has been lowered or raised in response to a change in the environment. This general phenomenon, which will be analysed in more detail in the next paper (Kjeldgaard, Maaløe \& Schaechter, 1958), accounts for the well-known fact that 'exponentially growing cells' are bigger than 'resting cells'. These common, descriptive terms are sometimes taken to mean that only two physiological cell types exist: a small, resting cell and a larger, exponentially growing cell. This is, however, too simple a picture. Under conditions of balanced growth, one of a large number of possible physiological states is established. These states are characterized by the size and chemical composition of the cell; they depend on the culture medium, are not grossly influenced by the temperature of cultivation and can probably be maintained as long as the genetic stability of the culture permits. At a given temperature, size and composition are found to depend in a simple manner on the growth rate afforded by the medium. This implies that media which give identical growth rates produce identical physiological states, regardless of the actual constituents of the media. The 'resting state' finds a natural place in this system since, in an outgrown broth culture, the size of the cells is reduced to approximately the value expected for zero growth rate (see Fig. 1).

We have so far considered only batch cultures where all the relevant nutrients are present in excess in the medium. Because the growth rate is limited by the type of nutrients and not by their concentration, we refer to this situation as 'unrestricted growth'. We assume that the growth rate observed under these conditions is the highest which can be attained with the set of nutrients available to the cell. In a continuous culture device of the type we employed, growth is 'restricted' by the rate at which, say, a required 
amino acid is added, i.e. by the low extra- and intracellular concentration of that component. Under conditions of unrestricted growth the concentration inside the cell of, say, an amino acid might similarly be thought of as being rate-limiting. This need not be the case, however, since, as discussed later, the growth rate may be controlled at the level of protein synthesis without involving limiting intracellular concentrations of amino acids, etc.

In our continuous culture experiments, new medium was added to the culture in pulses each of which momentarily increased the tryptophan concentration by 1-3 $\mu \mathrm{g} / 1$. According to Novick \& Szilard (1950) a constant tryptophan concentration of about $3 \mu \mathrm{g} / \mathrm{l}$. permits growth of Escherichia coli, strain $\mathrm{B} / 1, t$ at maximum rate; but below this concentration the growth rate rapidly decreases. Assuming a similar concentration dependency for strain tryA-8 of Salmonella typhimurium, every pulse of new medium will create conditions for growth at a relatively high rate for a short period. It is thus possible that, in our system, growth is intermittent, and that under such conditions, the growth rate during the pulse of growth afforded by a pulse of new medium, is not related to the dilution rate $D$ in the simple manner proposed by Monod (1950) and Novick \& Szilard (1950). We could therefore assume that the rate of synthesis during each pulse, rather than the overall rate, determines the size and chemical composition of the cell. However, experiments under more nearly ideal conditions of continuous growth are needed before the discrepancy between the results obtained under conditions of restricted and unrestricted growth can be properly analysed.

(2) Attempts to determine concurrently cell mass, nucleic acid content and the number of nuclei as functions of the growth rate have not previously been reported. Several pertinent studies exist in which one or more of these properties were related to the rate of growth. Thus, Wade (1952) obtained results which suggested a linear relation between RNA phosphorus/mg. $\mathbf{N}$ and the growth rate of Escherichia coli. Our data (Figs. 1, 2) indicate that this relation may actually be exponential; however, over the range studied by Wade and ourselves $(0 \cdot 6-2 \cdot 8$ generations/hr.), the increase in total RNA/unit mass (unlike RNA/cell) is at most twofold, and a clear distinction between linear and exponential functions therefore cannot be made. On the other hand, the overall increase is significantly less in Wade's experiments than in ours (50-60\% and $100 \%$, respectively). This difference may be due to the use by Wade of very large inocula (initial culture density: $2.5 \times 10^{8}$ to $10^{9}$ organisms/ $\mathrm{ml}$.). According to our experience the cells of such a dense culture would not reach, or maintain, the size and RNA concentration characteristic of balanced growth. Wade's careful measurements show that the high growth rate could not always be maintained throughout the experiment; the RNA concentrations, which were related to the initial growth rates, may therefore be low compared to the values which would have been obtained had growth been truly balanced.

Caldwell \& Hinshelwood (1950) and Caldwell, Mackor \& Hinshelwood (1950) determined the RNA concentration (in mg. RNA-phosphorus/mg. N) in different strains of Aerobacter aerogenes under various conditions. From the 
published data it cannot be ascertained whether balanced growth was attained, but their experiments also show that the faster the growth the higher the RNA concentration. In Aerobacter, the observed range of concentration is very high (three- to fourfold) perhaps because the lower growth rates were obtained by adding drugs to the medium or by using selected, slow-growing mutants.

Caldwell \& Hinshelwood (1950) also determined the DNA phosphorus in various cultures of Aerobacter aerogenes. With increasing values for total nitrogen/cell, a slight, but probably significant rise in DNA/cell was observed. No comparison between these figures and the growth rates can be derived from their data.

Perret (1958), studying Escherichia coli strain K12, measured the mean cell length and the number of intracellular structures which appeared as transverse light bands under the phase microscope (probably equivalent to the nuclei described here). He also found that, to the different growth rates obtained in different media and in continuous cultures correspond definite values of cell length and number of 'nuclei'. His figures for nuclei/cell correspond closely to those of Fig. 4.

(3) The existence of a variety of stable physiological states cannot be explained in a simple manner. What follows is an attempt to analyse the significant features of our experimental findings in terms of the major synthetic activities of the cells.

Cytological evidence strongly suggests that the stained bodies referred to as 'nuclei' contain DNA, and we shall assume that most, if not all, the DNA of the cell is located there. A comparison of Figs. 3 and 4 shows that the amount of DNA per stained body is nearly constant, as would be expected if each body represents a nucleus in the physiological and genetic sense. With this in mind it seems opportune to differentiate between variation on the cellular and on the nuclear level. Since at low growth rates the majority of cells are uninucleated it seems natural to consider a single nucleus plus its corresponding cytoplasm, cell wall, etc., as an elementary unit. Multinucleated cells, composed of two or more such units can be thought of as syncytial. We will therefore distinguish between changes in the number of elementary units/cell and in mass/elementary unit. The way in which changes in the number of elementary units/cell come about is treated in the second paper of this series.

The variation in mass per elementary unit will be analysed below in accordance with the following assumptions: (a) that a large fraction of the cell's RNA is in the form of ribonucleoprotein particles consisting of about equal parts of RNA and protein and with molecular weight about one million (Schachman, Pardee \& Stanier, 1952; Tissières \& Watson, 1958); (b) that, per nucleus, the cell contains fixed amounts of DNA, cell wall and cell membrane material, varying amounts of free RNA and particles and, finally, a pool of soluble protein and other compounds; and $(c)$ that this pool is always made up largely of protein.

The first assumption is supported by data from Wade \& Morgan (1957). Comparing resting cells of Escherichia coli with cells growing in a complex medium these authors found that the RNA-pentose of particles sedimenting 


\section{Cell size and composition in different media}

completely in $4 \mathrm{hr}$. at $100,000 \mathrm{~g}$ amounted respectively to about 50 and $75 \%$ of the total RNA-pentose. The second assumption is based on estimates of cell diameters and lengths (cf. p. 598) from which it can be estimated that the surface area/nucleus is virtually constant. The actual weight ascribed to cell wall and membrane (see Table 3 ) is of little importance for our conclusions. The third assumption seems more gratuitous; however, the greater part of the protein of the cell must be in the pool, and since this never exceeds about $60 \%$ of the cell weight (Table 3, column 7) it is fair to assume that the bulk of the pool is protein (free enzymes).

Table 3. Relative rates of protein synthesis

1 $\mathbf{2}$

3

$\begin{array}{ccc}\begin{array}{c}\text { Doublings/ } \\ \text { hr. }\end{array} & \begin{array}{c}\text { Dry } \\ \text { weight/ } \\ \text { cell* }\end{array} & \begin{array}{c}\text { Nuclei/ } \\ \text { cell }\end{array} \\ 0 \cdot 6 & 240 & 1 \cdot 25 \S \\ 1 \cdot 2 & 360 & 1 \cdot 10 \\ 2 \cdot 4 & 840 & 2 \cdot 40 \\ 2 \cdot 8 & 1090 & 2 \cdot 90\end{array}$

4

5

6

$\begin{array}{cc}\begin{array}{c}\text { Dry } \\ \text { weight/ } \\ \text { nucleus* }\end{array} & \begin{array}{c}\text { RNA/ } \\ \text { nucleus* }\end{array} \\ 192 & 19 \\ 218 & 22 \\ 250 & 31 \\ 350 & 65 \\ 376 & 84\end{array}$

6
Particles/
nucleus $†$
11,300
13,300
22,400
54,000
81,000

7
Pool
material/
nucleus* $\$$
100
120
135
176
160

\begin{tabular}{|c|c|}
\hline \multicolumn{2}{|c|}{$\begin{array}{cc}8 & 9 \\
\text { Pool + particle protein } \\
\text { synthesized/min.* }\end{array}$} \\
\hline $\begin{array}{c}\text { Per } \\
\text { nucleus }\end{array}$ & $\begin{array}{c}\text { Per } \\
\text { particle } \\
\left(\times 10^{4}\right)\end{array}$ \\
\hline $1 \cdot 1$ & 0.98 \\
\hline $1 \cdot 3$ & 1.0 \\
\hline $3 \cdot 1$ & $1 \cdot 4$ \\
\hline $8 \cdot 8$ & $1 \cdot 6$ \\
\hline $10 \cdot 6$ & 1.3 \\
\hline
\end{tabular}

* All weights in $\mathrm{g} . \times 10^{15}$.

$\dagger$ Calculated on the assumption that, from top to bottom, 50,60,70 and $80 \%$ of the RNA is in particles of molecular weight one million, and composed of equal parts of protein and RNA.

$\ddagger$ Per nucleus, the cell is assumed to consist of: $65 \times 10^{-15} \mathrm{~g}$. of wall, membrane and nuclear material, i.e. about one-third by weight of the smallest cell type; $(b)$ particles and free RNA; and (c) a pool mainly containing soluble protein.

\$ Two values given : above, the one directly observed; below, that obtained by extrapolating the linear part of the curve of Fig. 4 (see p. 597).

Table 3 shows representative figures for mass, average number of nuclei/ cell and mass and RNA/nucleus, taken from Figs. 1, 2, and 4 (columns 2, 3, $4,5)$. The right-hand side of the Table contains calculations based on these values and on the assumptions listed above. The number of particles and the pool size per nucleus are presented in columns 6 and 7 . The relatively small changes in pool size show that variation in mass/nucleus is due mainly to rariation in number of particles/nucleus.

In Table 3, column 8 presents maximum values for the synthesis of protein/ nucleus/min. (assuming the pool to be all protein and adding to that the particle protein). It is apparent that the rate of protein synthesis is directly proportional to the amount of RNA, or the number of particles, and that both increase in rough proportion to the growth rate. Small variations in the soluble protein fraction of the pool or in the particle fraction of RNA do not seriously affect these trends. The rate of protein synthesis/unit RNA, or per particle, thus is nearly independent of the growth rate (column 9). This conclusion is of considerable interest because recent biochemical evidence indicates that these particles, which are analogous to the 'microsomal 
particles' of animal cells, are directly concerned with protein synthesis (see, for example, review by Crick, 1958).

The constancy of the rate of protein synthesis/particle is most readily interpreted on the simple assumption that all particles participate equally in protein synthesis. This may, however, not be the case. By studying externally induced synthesis of $\beta$-galactosidase, it has been possible to show that the enzyme-forming system remains intact during growth in the absence of an inducer (Monod, Pappenheimer \& Cohen-Bazire, 1952). If we tentatively identify the system producing $\beta$-galactosidase with one class of particles, we have a case where particles which continue to be reproduced remain virtually inactive unless an inducer is present. Addition to a culture of, say, an amino acid may cause repression of enzymes concerned with the synthesis of the added compound (see, for example, Vogel, 1957), and it is sometimes taken for granted that the process of repression also involves a reduction of the size of the enzyme-forming systems. If this is not true, as suggested by the results of Monod et al. (1952), cells growing in a complex medium would contain a certain fraction of inactive particles (corresponding to the repressed enzymes), whereas cells grown in minimal medium would contain predominantly active ones (little or no repression).

Without knowing what fraction of the particles is actively synthesizing, the true rate of protein synthesis/particle cannot be estimated. Despite this uncertainty it is clear that, unless a majority of the particles are rendered inactive during growth in complex media, the rate of protein synthesis per particle increases much less than does the growth rate.

It is attractive to imagine that the system responsible for a particularly complex process like protein synthesis perhaps functions with nearly the same efficiency under very different growth conditions (with the reservation, of course, that certain enzyme-forming systems may have their function specifically repressed). Addition to a culture growing in minimal medium of compounds like amino acids, purines or pyrimidines increases the growth rate presumably by relieving the cells of the necessity for synthesizing the added compounds. If one assumes that the economy of cell growth is actually based on maintaining a high efficiency of protein synthesis it is evident that an increase in growth rate is possible only if the protein synthesizing system of the individual cell is expanded; i.e. if the number of particles/nucleus is increased. For this to happen, the addition of, say, amino acids to the medium must cause a definite increase in the rate of RNA synthesis which, in turn, brings about the observed, but smaller increase in growth rate.

In the next paper we shall see that, in agreement with this hypothesis, the initial effect of adding amino acids or broth to a minimal medium culture is to stimulate RNA synthesis preferentially.

We wish hereby to acknowledge the expert technical assistance of $\mathrm{Mr} \mathrm{O}$. Rostock, One of the authors (M.S.) was aided by a post-doctoral fellowship grant from the American Cancer Society and one (N.O.K.) by grants from the Danish National Science Foundation and the Lilly Research Foundation. 


\section{Cell size and composition in different media}

\section{REFERENCES}

Burton, K. (1956). A study of the conditions and mechanism of the diphenylamine reaction for the colorimetric estimation of deoxyribonucleic acid. Biochem. J. $62,315$.

Caldwell, P. C. \& Hinshelwood, C. (1950). The nucleic acid content of Bact. lactis aerogenes. J. chem. Soc. 1415.

Caldwell, P. C., Mackor, E. L. \& Hinshelwood, C. (1950). The ribonucleic acid content and cell growth of Bact. lactis aerogenes. J. chem. Soc. 3151.

Camprell, A. (1957). Synchronization of cell division. Bact. Rev. 21, 263.

Crick, F. H. C. (1958). On protein synthesis. Symp. Soc. expl. Biol. N.Y. (in the Press).

Formal, S. B., Baron, L. S. \& Spilman, W. (1956). The virulence and immunogenicity of Salmonella typhosa grown in continuous culture. J. Bact. 72, 168.

Gale, E. F. \& Folkes, J. P. (1953). The assimilation of amino-acids by bacteria. 14. Nucleic acid and protein synthesis in Staphylococcus aureus. Biochem. J. 53, 483.

Hennici, A. T. (1928). Morphologic variation and the rate of growth of bacteria. Microbiology Monographs. London: Baillière, Tindall and Cox.

Herbert, D., Elsworth, R. \& Telling, R. C. (1956). The continuous culture of bacteria: a theoretical and experimental study. J. gen. Microbiol. 14, 601.

Kerr, S. E. \& Seraidarian, K. (1945). The separation of purine nucleosides from free purines and the determination of the purines and ribose in these fractions. J. biol. Chem. 159, 211.

KJeldgaArd, N. O., Maalge, O. Schaechter, M. (1958). The transition between different physiological states during balanced growth of Salmonella typhimurium. J. gen. Microbiol. 19, 607.

LARK, K. G. \& MAALøE, O. (1954). The induction of cellular and nuclear division in Salmonella typhimurium by means of temperature shifts. Biochim. biophys. Acta, 15, 345.

Lark, K. G. \& MaAløe, O. (1956). Nucleic acid synthesis and the division cycle of Salmonella typhimurium. Biochim. biophys. Acta, 21, 448.

LarK, K. G., MaAløe, O. \& Rostock, O. (1955). Cytological studies of nuclear division in Salmonella typhimurium. J. gen. Microbiol. 13, 318.

Malmgren, B. \& Hedén, C. (1947). Studies of the nucleotide metabolism of bacteria. III. The nucleotide metabolism of Gram negative bacteria. Acta path. microbiol, scand. 24, 448.

Monod, J. (1950). La technique de culture continue, théorie et applications. Ann. Inst. Pasteur, 79, 390.

Monod, J., Pappenheimer, A. M. \& Cohen-Bazire, G. (1952). La cinétique de la biosynthèse de la $\beta$-galactosidase chez $E$. coli considérée comme fonction de la croissance. Biochim. biophys. Acta, 9, 648.

Morse, M. L. \& CARTER, C. E. (1949). The synthesis of nucleic acids in cultures of Escherichia coli strains $B$ and B/r. J. Bact. 58, 317.

Novick, A. \& Szilard, L. (1950). Experiments with the chemostat on spontaneous mutations of bacteria. Proc. nat. Acad. Sci. 36, 708.

Perret, C. J. (1958). The effect of growth-rate on the anatomy of Escherichia coli. J. gen. Microbiol. 18, vii.

Powell, E. O. (1956). Growth rate and generation time of bacteria, with special reference to continuous culture. J. gen. Microbiol. 15, 492.

Ross, K. F. A. (1957). The size of living bacteria. Quart. J. micr. Sci. 98, 435.

Salk, J. E., Youngner, J. S. \& Ward, E. N. (1954). Use of color change of phenol red as the indicator in titrating poliomyelitis virus or its antibody in a tissueculture system. Amer. J. Hyg. 50, 214.

Schachman, H. K., Pardee, A. B. \& Stanier, R. Y. (1952). Studies on the macromolecular organization of microbial cells. Arch. Biochem. Biophys. 38, 245. 
606 M. Schaechter, O. Maalфe and N. O. Kjeldgaard

Tissimpes, A. \& Watson, J. D. (1958). Ribonucleoprotein particles from Escherichia coli. Nature, Lond. $182,778$.

VOGEL, H. J. (1957). Repression and induction as control mechanisms of enzyme biogenesis: the 'adaptive' formation of acetylornithase. In Chemical Basis of Heredity, p. 276. Baltimore: The Johns Hopkins Press.

WADE, H. E. (1952). Variation in the phosphorus content of Escherichia coli during cultivation. J. gen. Microbiol. 7, 24.

WADE, H. E. \& MoRgAN, D. M. (1957). The nature of the fluctuating ribonucleic acid in Escherichia coli. Biochem. J. 65, 321 .

(Received 19 June 1958) 